\begin{tabular}{cc|c}
\hline Tar. Bil. Der. & Journal of Agricultural Sciences \\
& $\begin{array}{c}\text { Dergi web sayfası: } \\
\text { www.agri.ankara.edu.tr/dergi }\end{array}$ & Journal homepage: \\
& www.agri.ankara.edu.tr/journal
\end{tabular}

\title{
Effects of Irrigation Programs Formed by Different Approaches on the Yield and Water Consumption of Black Cumin (Nigella sativa L.) under Transition Zone in the West Anatolia Conditions
}

\author{
Ulas SENYIGITT ${ }^{\mathrm{a}}$, Mustafa ARSLAN ${ }^{\mathrm{b}}$ \\ ${ }^{a}$ Suleyman Demirel University, Faculty of Agriculture, Department of Agricultural Structures and Irrigation, 32260, Isparta, TURKEY \\ ${ }^{\boldsymbol{b}}$ Ministry of Food, Agriculture and Livestock, Afyonkarahisar Provincial Directorate, Afyonkarahisar, TURKEY
}

\section{ARTICLE INFO}

Research Article

DOI: 10.15832 /ankutbd.446366

Corresponding Author: Ulas SENYIGIT, E-mail: ulassenyigit@sdu.edu.tr, Tel: +90 (246) 2118564

Received: 07 June 2016, Received in Revised Form: 19 September 2016, Accepted: 19 September 2016

\begin{abstract}
This study was carried out to determine the effects of different irrigation programs obtained by pan evaporation and water balance methods on some yield and vegetative parameters and water consumption of black cumin in the experiment field located in the center of Cobanlar District in Afyonkarahisar, Turkey during 2013 and 2014 growing seasons. In the experiment, the irrigation treatments were formed with 3 different irrigation intervals (SA3: 3 days, SA5: 5 days, and SA10: 10 days) and 4 different irrigation water levels as $0 \%\left(\mathrm{I}_{0}\right.$ : non-irrigated) $50 \%, 75 \%\left(\mathrm{I}_{50}, \mathrm{I}_{75}\right.$ : deficit irrigation) and $100 \%\left(\mathrm{I}_{100}\right.$ : full irrigation) of the cumulative evaporation amount measured from class A pan in the first year and, of the required water amount to replenish the available soil moisture to the field capacity in the $0.60 \mathrm{~m}$ soil depth in the second year. The highest and the lowest evapotranspiration (ET) values were determined as $387.6 \mathrm{~mm}$ in SA3- $\mathrm{I}_{100}$ and as $166.9 \mathrm{~mm}$ in $\mathrm{I}_{0}$, respectively. The highest seed yield was obtained in SA5- $\mathrm{I}_{100}$ with an amount of $1700.6 \mathrm{~kg}^{-1}$ while the lowest seed yield was obtained in $\mathrm{I}_{0}$ with an amount of $722.2 \mathrm{~kg} \mathrm{ha}^{-1}$. The highest total water use efficiency (WUE) and irrigation water use efficiency (IWUE) values were calculated from SA5- $\mathrm{I}_{50}$ as $5.11 \mathrm{~kg} \mathrm{ha}^{-1} \mathrm{~mm}^{-1}$ and $4.80 \mathrm{~kg} \mathrm{ha}^{-1} \mathrm{~mm}^{-1}$, respectively. While the yield response factor values (ky) were obtained as 0.75 (SA3), 0.80 (SA5) and 0.50 (SA10) for different irrigation interval, the mean ky value was determined as 0.68 according to all treatments of both years. Since the values of the yield and vegetative parameters and ET in same irrigation programs formed by two different methods were close to each other, the both methods can be used for irrigation of black cumin.
\end{abstract}

Keywords: Evapotranspiration; Drip irrigation; Water use efficiency; Yield response factor

\section{Batı Anadolu Koşullarındaki Geçiş Bölgesi Altında Farklı Yaklaşımlar ile Oluşturulan Sulama Programlarının Çörekotu (Nigella sativa L.) Bitkisinin Verim ve Su Tüketimine Etkileri}

\section{ESER BİLGİSI}

Araștırma Makalesi

Sorumlu Yazar: Ulas SENYIGIT, E-posta: ulassenyigit@sdu.edu.tr, Tel: +90 (246) 2118564

Geliş Tarihi: 07 Haziran 2016, Düzeltmelerin Gelişi: 19 Eylül 2016, Kabul: 19 Eylül 2016 


\section{ÖZET}

$\mathrm{Bu}$ çalışma, buharlaşma kabı ve toprak nem dengesine göre elde edilen farklı sulama programlarının çörekotu bitkisinin verim ve vejetatif özellikleri ile su tüketimine etkisini belirlemek amacıyla 2013-2014 yetişme sezonlarında, Afyonkarahisar İli Çobanlar İlçesi merkezinde yer alan deneme alanında yürütülmüştür. Çalışmada, sulama konuları 3 farklı sulama aralığı (SA3: 3 gün, SA5: 5 gün ve SA10: 10 gün) ve ilk y1l A sınıfı buharlaşma kabında ölçülen yığışımlı buharlaşma miktarının, ikinci yıl ise $0.60 \mathrm{~m}$ toprak derinliğindeki mevcut nemi tarla kapasitesine çıkarmak için gerekli olan sulama suyu miktarının \% 0 ( $\mathrm{I}_{0}$ : sulama yapılmayan), \% 50, \% $75\left(\mathrm{I}_{50}, \mathrm{I}_{75}:\right.$ kısıntılı sulama) ve \% $100\left(\mathrm{I}_{100}:\right.$ tam sulama)'ünün uygulandığı 4 farklı sulama suyu düzeyi konularından oluşturulmuştur. En yüksek ve düşük bitki su tüketimi (ET) değerleri sırasıyla, SA3- $\mathrm{I}_{100}$ konusundan $387.6 \mathrm{~mm}$ ve $\mathrm{I}_{0}$ konusundan $166.9 \mathrm{~mm}$ olarak saptanmıştır. Çalışmada, en yüksek tohum verimi $1700.6 \mathrm{~kg} \mathrm{ha}^{-1}$ ile SA5-I ${ }_{100}$ konusundan elde edilirken, en düşük $722.2 \mathrm{~kg} \mathrm{ha}^{-1}$ ile $\mathrm{I}_{0}$ konusundan elde edilmiştir. Denemede en yüksek toplam su kulanım randımanı (WUE) ve sulama suyu kullanım

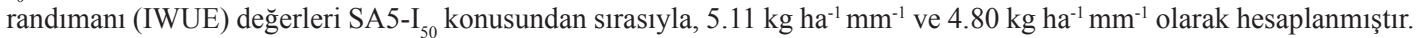
Verim tepki etmeni (ky) değerleri farklı sulama aralığı konularından 0.75 (SA3), 0.80 (SA5) ve 0.50 (SA10) olarak elde edilirken, her iki yılın değerleri göz önüne alındığında tüm konular için ortalama ky değeri 0.68 olarak belirlenmiştir. İki farklı yöntemle oluşturulan aynı sulama programlarından elde edilen verim, vejetatif özellikler ve ET değerlerinin birbirine yakın olması, çörekotu bitkisinin sulanmasında her iki yönteminde kullanılabileceğini göstermiştir.

Anahtar Kelimeler: Bitki su tüketimi; Damla sulama; Su kullanım randımanı; Verim tepki etmeni

(C) Ankara Üniversitesi Ziraat Fakültesi

\section{Introduction}

Black cumin (Nigella sativa L.) which has an important place among medicinal and aromatic plants is an annual herbaceous plant from Ranunculaceae family. Because of the fixed oil, volatile oil and other nutrients in its seed, black cumin is highly valued in health and food industries. Nowadays, due to the consumption needs of the rapidly increasing world population, black cumin, the consumption in the world based on very old ages, has a quite large market which is about $\$ 60$ billion (Kumar 2009). Within the total production of 3520 tons in 326.1 ha area in Turkey, Afyonkarahisar ranks third with 180 tons of production in 12.3 ha area after Bursa and Sivas provinces. In recent years in Turkey, despite the decrease in the production of black cumin, consumption is rapidly increasing. Black cumin export declined from 160 tons (\$243 thousand) to 57 tons (\$224 thousand) whereas import increased from 50 tons ( $\$ 25$ thousand) to 2933 tons ( $\$ 2.8$ million) between 2001 and 2014 years (TUIK 2015). The vast majority of medicinal and aromatic plants are collected as wild from nature in Turkey as in other areas of the world, and their cultivation is not performed (Baydar 2013). When the mentioned import and export amounts are taken into consideration, the increasing of production amount by the culture of the black cumin plant and irrigated agriculture is expected to contribute to the farmers by meeting the demands of both domestic and foreign markets. Water is one of the most important sources for the agricultural production has become quite limited in both quantity and quality aspects due to the rapidly increasing population and industrialization. Especially, as demand for irrigation water increases in arid and semi-arid regions, the need for water-yield functions revealing the relationship between the yield and irrigation water and evapotranspiration, used to determine the optimum irrigation management also increases. Evapotranspiration is crucial in the economic use of water, the preparation of irrigation programs and the management of agricultural water (Yazar et al 2002; Panda et al 2004). The pan evaporation method is practicable for farmers and commonly used method for the irrigation scheduling of plants because of the simple application and close correlation between evapotranspiration and pan evaporation (Kanber 1984; Wang et al 2009). For inadequate water conditions, with the using of irrigation techniques called as deficit irrigation, it is aimed to save the inputs such as irrigation water, 
labor and energy, as well as to increase the water use efficiency (WUE) which means the yield obtained from a unit of water (English \& Raja 1996). The yield response factor (ky), which is an important parameter showing the linear relationship between the relative evapotranspiration deficit and the relative yield decrease, is a very important guide for the determination whether a plant is tolerate or sensitive by taking into consideration the response to water shortage (Doorenbos \& Kassam 1986). Despite many studies performed on the yield and vegetative parameters of the black cumin plant (Kalcin 2003; Ozel et al 2009; Akgoren 2011; Taqi 2013; Safaei et al 2014), in a limited number of the studies especially performed on the irrigation practices and wateryield functions in deficit irrigation conditions. While Ghamarnia et al (2010) obtained the seasonal plant water consumption within 414-1461 $\mathrm{mm}$ and water use efficiency (WUE) values within $0.49-1.39 \mathrm{~kg}$ $\mathrm{ha}^{-1} \mathrm{~mm}^{-1}$, Ghamarnia \& Jalili (2013) determined the same values as $193-645 \mathrm{~mm}$ and $0.11-1.87 \mathrm{~kg} \mathrm{ha}^{-1}$ $\mathrm{mm}^{-1}$, respectively.
Since the black cumin plant is generally cultivated in unirrigated conditions, the reaction of the plant to scheduled irrigation is very important in terms of yield and the optimal use of water. In this study, it was aimed to determine the effects of irrigation programs obtained by pan evaporation and water balance methods on some yield and vegetative parameters, seasonal evapotranspiration and water-yield functions of black cumin.

\section{Material and Methods}

\subsection{Experimental area, climate, soil and irrigation water features}

The experiment was conducted in a field located in Cobanlar District of Afyonkarahisar Province $\left(38^{\circ} 41^{\prime} 59.07^{\prime \prime} \mathrm{N}, 30^{\circ} 47^{\prime} 34.03\right.$ ' E and $1013 \mathrm{~m}$ altitude). Since the experimental area is away from the sea and surrounded by mountains, it has a typical continental climate. Some climate data for the longterm and vegetation periods of experimental years were given in Table 1.

Table 1- Monthly some climate data in the growing season for the long-term and the experiment years

\begin{tabular}{|c|c|c|c|c|c|c|c|}
\hline \multirow{2}{*}{ Climate data } & \multirow{2}{*}{ Year } & \multicolumn{5}{|c|}{ Month } & \multirow{2}{*}{ Average } \\
\hline & & March & April & May & June & July & \\
\hline \multirow{3}{*}{$\begin{array}{l}\text { Temperature } \\
\left({ }^{\circ} \mathrm{C}\right)\end{array}$} & 2013 & 7.8 & 11.2 & 17.7 & 20.6 & 21.9 & 15.8 \\
\hline & 2014 & 7.0 & 12.0 & 15.1 & 18.6 & 23.5 & 15.2 \\
\hline & Long-term* & 5.4 & 10.3 & 15.0 & 19.1 & 22.3 & 14.4 \\
\hline \multirow{3}{*}{$\begin{array}{l}\text { Sunshine duration } \\
\text { (hour) }\end{array}$} & 2013 & 5.6 & 7.0 & 9.4 & 11.2 & 13.2 & 9.3 \\
\hline & 2014 & 5.3 & 6.3 & 8.3 & 9.8 & 10.7 & 8.1 \\
\hline & Long-term & 5.1 & 6.2 & 8.2 & 10.0 & 11.2 & 8.1 \\
\hline \multirow{3}{*}{$\begin{array}{l}\text { Precipitation } \\
(\mathrm{mm})\end{array}$} & 2013 & 29.2 & 34.6 & 22.2 & 11.6 & 57.2 & 154.8 \\
\hline & 2014 & 25.4 & 17.6 & 66.2 & 52.4 & 0.4 & 162.0 \\
\hline & Long-term & 43.5 & 46.9 & 47.6 & 35.0 & 19.0 & 192.0 \\
\hline \multirow{3}{*}{ Relative humidity (\%) } & 2013 & 58.5 & 62.2 & 51.9 & 48.0 & 47.7 & 53.7 \\
\hline & 2014 & 74.3 & 63.9 & 68.3 & 67.3 & 52.4 & 65.2 \\
\hline & Long-term & 73.0 & 69.1 & 54.1 & 62.8 & 66.4 & 65.1 \\
\hline \multirow{3}{*}{$\begin{array}{l}\text { Wind speed } \\
\left(\mathrm{m} \mathrm{s}^{-1}\right)\end{array}$} & 2013 & 2.1 & 1.8 & 1.8 & 2.0 & 2.1 & 2.0 \\
\hline & 2014 & 3.1 & 2.8 & 2.6 & 2.4 & 2.5 & 2.7 \\
\hline & Long-term & 2.0 & 2.2 & 1.8 & 1.7 & 2.2 & 2.0 \\
\hline \multirow{3}{*}{$\begin{array}{l}\text { Evaporation } \\
(\mathrm{mm})\end{array}$} & 2013 & - & 101.0 & 191.8 & 237.3 & 249.3 & 779.4 \\
\hline & 2014 & - & 86.2 & 137.7 & 180.2 & 266.6 & 670.7 \\
\hline & Long-term & 2.0 & 73.2 & 145.4 & 188.1 & 241.3 & 650.0 \\
\hline
\end{tabular}

*, between the years 1970 and 2013 
Some physical properties of the experimental area soil were presented in Table 2. Available soil water holding capacity was $102.09 \mathrm{~mm}$ for $0-60$ $\mathrm{cm}$. The irrigation water used in the experiment was obtained from the well located next to the field with $1.8 \mathrm{~L} \mathrm{~s}^{-1}$ flow rate and $\mathrm{C}_{3} \mathrm{~S}_{1}$ qualified.

Table 2- Soil physical characteristics of the experimental area

\begin{tabular}{lllllll}
\hline $\begin{array}{l}\text { Soil depth } \\
(\mathrm{cm})\end{array}$ & $\begin{array}{l}\text { Bulk density } \\
\left(\mathrm{g} \mathrm{cm} \mathrm{cm}^{-3}\right)\end{array}$ & Texture & $\begin{array}{l}\text { Field capacity } \\
(\%)\end{array}$ & $\begin{array}{l}\text { Wilting point } \\
(\%)\end{array}$ & $\begin{array}{l}\text { Water holding capacity } \\
(\%)\end{array}$ & $\begin{array}{l}(\mathrm{mm}) \\
(0-30\end{array}$ \\
\hline 1.32 & $\mathrm{CL}$ & 28.63 & 17.78 & 10.85 & 42.96 \\
$30-60$ & 1.46 & $\mathrm{SCL}$ & 24.71 & 11.21 & 13.50 & 59.13 \\
$60-90$ & 1.35 & $\mathrm{SCL}$ & 29.15 & 11.68 & 17.47 & 70.75 \\
\hline
\end{tabular}

\subsection{Experiment treatments, planting, cultural practices and design of drip irrigation system}

The study was carried out according to the factorial arrangement in completely randomized plots design with three replications. In the experiment, while class A pan was used in the first year (2013), the available moisture at $60 \mathrm{~cm}$ soil depth was monitored with the gravimetric method in the second year (2014) in order to determine the amount of the irrigation water. The two approaches widely used for forming the irrigation program, were compared with use of actual data obtained from each experimental years. The irrigation treatments were formed with 3 different irrigation intervals (SA3: 3 days, SA5: 5 days, and SA10: 10 days) and 4 different irrigation water levels for each irrigation interval as $0 \%$ (Nonirrigated: $\mathrm{I}_{0}$ ) $50 \%, 75 \%$ (Deficit irrigation: $\mathrm{I}_{50}, \mathrm{I}_{75}$ ) and $100 \%$ (Full irrigation: $\mathrm{I}_{100}$ ) of the amount of the measured cumulative evaporation in the first year and, of the amount of required water to replenish the available soil water to the field capacity in the second year.

The experimental area consisted of a total of 30 plots. The area of each plot was $1.62 \mathrm{~m}^{2}(0.90 \times 1.80$ $\mathrm{m})$, and the total area was $208.0 \mathrm{~m}^{2}(10.4 \times 20.0 \mathrm{~m})$. In order to prevent the interaction between irrigation treatments, $1 \mathrm{~m}$ space was left between the plots. Besides, two rows in each plot were left out of the assessment due to the edge effect, and the remaining area formed the harvest plots.

Black cumin (Nigella sativa L.) seed sowing was performed in the plots in the last week of March in both years (25 March 2013-26 March 2014) to be $0.2 \mathrm{~kg}$ per hectare. Following the germination, plants were diluted to ensure $15 \times 10 \mathrm{~cm}$ plant spacing. The nutrient requirement of plants was determined according to the soil analysis (no $\mathrm{K}_{2} \mathrm{O}$ was needed; $\mathrm{P}_{2} \mathrm{O}_{5}$ and $\mathrm{N}$ were applied at a rate of $55 \mathrm{~kg} \mathrm{ha}^{-1}$ and $40 \mathrm{~kg} \mathrm{ha}^{-1}$, respectively). A half of the total nutrient amount was given during the preparation of soil, and remaining amount was given with the fertigation technique as equal amounts during the irrigation period by dividing into the number of irrigation. Engineering and operating principles of the drip irrigation system was designed according to the fundamentals given by Kanber (2010). Thus, emitter spacing was $20 \mathrm{~cm}$, dripper discharge was $4 \mathrm{~L} \mathrm{~h}^{-1}$, PE lateral diameter was $16 \mathrm{~mm}$, main pipe diameter was $50 \mathrm{~mm}$, and a single lateral was placed for each two rows.

\subsection{Irrigation water, evapotranspiration and water-yield functions}

While the amount of the applied irrigation water to the treatments was calculated using Equation 1 in the first year (2013), Equation 2 was used in the second year (2014). The amount of irrigation water determined as depth terms, was calculated in volume terms by multiplying with the parcel unit area and the percentage of the wetted area during the applications (Equation 3).

$$
\begin{aligned}
& I=E p a n \times K p \times S d \\
& I=(F C-A W) \times S d \\
& V=I \times A \times W A
\end{aligned}
$$


Where; I, irrigation water amount (mm); Epan, cumulative evaporation amount from the class A pan during the irrigation interval according to the treatments $(\mathrm{mm})$; Kp, pan coefficient (taken as 0.77 based on the principles given by Doorenbos \& Pruitt (1977)); Sd, irrigation water level; FC, field capacity (mm); AW, available water in the soil within $60 \mathrm{~cm}$ depth before irrigation applications $(\mathrm{mm}) ; \mathrm{V}$, irrigation water as volume (L); $A$, plot area $\left(\mathrm{m}^{2}\right)$; WA, percentage of the wetted area $(67 \%)$.

The evapotranspiration for the treatments was calculated using Equation 4 based on the water balance (James 1988).

$E T=I+P+C p \pm \mathrm{r} S W-D p-R f$

Where; ET, evapotranspiration (mm); P, precipitation $(\mathrm{mm})$; Dp, deep percolation $(\mathrm{mm})$; $\mathrm{rSW}$, change in the soil water storage in the $60 \mathrm{~cm}$ depth (mm); Rf, runoff (mm); Cp, amount of water entering the root zone with capilaric rise $(\mathrm{mm})$.

Regression analyzes were performed by establishing graphical relations between total irrigation water and seed yield values, and evapotranspiration and seed yield values. Besides, Equation 5, 6 and 7 were used to calculate the water use efficiency (WUE), irrigation water use efficiency (IWUE), and the coverage ratio of the applied irrigation water to the evapotranspiration (IRc) relating to the treatments (Howell et al 1990).

$$
\begin{aligned}
& W U E=Y / E T \\
& I W U E=\left(Y-Y_{0}\right) / I \\
& I R c=(I / E T) \times 100
\end{aligned}
$$

Where; Y, seed yield obtained from the treatments $\left(\mathrm{kg} \mathrm{ha}^{-1}\right) ; \mathrm{Y}_{0}$, seed yield obtained from $\mathrm{I}_{0}\left(\mathrm{~kg} \mathrm{ha}^{-1}\right)$.

The yield response factor (ky) representing the decrease in the black cumin seed yield which occurred as a result of the decrease in the unit evapotranspiration was determined using Equation 8 (Doorenbos \& Kassam 1986).

$$
(1-Y a / Y m)=k y(1-E T a / E T m)
$$

Where; Ya, actual seed yield regarding the treatments $\left(\mathrm{kg} \mathrm{ha}^{-1}\right)$; Ym, maximum seed yield $\left(\mathrm{kg} \mathrm{ha}^{-1}\right)$; Eta, actual seasonal evapotranspiration regarding the treatments $(\mathrm{mm})$; Etm, maximum seasonal evapotranspiration $(\mathrm{mm})$.

\subsection{The effective root depth, some yield, and vegetative parameters}

In order to determine the effective root depth of black cumin, the full irrigation treatment $\left(\mathrm{I}_{100}\right)$ was monitored, and the depth consumed $85 \%$ of the amount of water required for normal development of the plants was taken into account (Kanber 1997). Plant height $(\mathrm{cm})$, the number of branches (number plant $^{-1}$ ), and plant capsule number (number plant ${ }^{-1}$ ) values were determined by measuring and counting before harvest. Following the harvest, seed number in capsules (number capsule ${ }^{-1}$ ) was determined by counting and seed yield $\left(\mathrm{kg} \mathrm{ha}^{-1}\right)$ was determined by dividing the unit area of the total weight. In addition, thousand seed weight $(\mathrm{g})$ was determined by multiplying the weight of 100 seeds which was measured with sensitive scales with 10 , and the harvest index (\%) was determined by the proportion of the weight of seeds harvested from 10 plants with the weight of the unharvested plant.

\subsection{Statistical analysis}

In order to determine the effects of the irrigation treatments on the some yield and vegetative parameters of black cumin for each year, data were performed to the variance analysis using Minitab ${ }^{\circledR}$ 16.2.4 computer software package, and Tukey's comparison test was used to determine the differences between the mean values $(\mathrm{P}<0.05)$.

\section{Results and Discussion}

\subsection{Irrigation water, evapotranspiration and yield}

The irrigation period was between $23^{\text {rd }}$ May and $12^{\text {th }}$ July 2013 in the first year, and between $25^{\text {th }}$ May and $17^{\text {th }}$ July 2014 in the second year. The highest irrigation water amount was applied in SA5- $\mathrm{I}_{100}$ as $255.6 \mathrm{~mm}$, and the lowest irrigation water amount was applied in $\mathrm{SA} 3-\mathrm{I}_{50}$ as $97.0 \mathrm{~mm}$ 
(Table 3). It can be said that the reason for the fact that the total irrigation water amount in the second year was lower according to the first year, that pan evaporation methods were used to determine the irrigation water amount in the first year, and that the amount of precipitation was higher than both the long-term value and the value in the first year of the vegetation period (from May to June).

ET values varied at both different irrigation water amounts and irrigation intervals. The highest ET values were calculated in SA3- $\mathrm{I}_{100}$ in both years as 334.8 and $387.6 \mathrm{~mm}$, respectively, whereas the lowest ET values were measured in $\mathrm{I}_{0}$ in which no irrigation was applied in the both years as 212.8 and $166.9 \mathrm{~mm}$, respectively (Table 3). In general, ET values obtained from same irrigation programs formed by different methods among the years were similar. ET values increased with the amount of applied irrigation water increased. Additionally, higher ET values were also obtained from more frequent irrigation (3 days) compared to less frequent irrigation ( 5 and 10 days) in the treatments where applied similar water amount. While the applied irrigation water amount in the study was less than those obtained by some other researchers, ET values were similar in general (Ghamarnia \& Jalili 2013; Ghamarnia et al 2010).

Soil water content was close to the field capacity (FC) at $143^{\text {rd }}$ day of the year (2013) and $145^{\text {th }}$ day of the year (2014) in all treatments. Then, soil water contents before irrigation showed a tendency to decrease in all treatments (Figure 1). A dramatic decrease was observed in the soil water content values in the $I_{0}$ and $I_{50}$ treatments and the values were close to or lower than permanent wilting point (PWP). Soil water content decreased with

Table 3- Irrigation water, evapotranspiration, water use efficiencies

\begin{tabular}{|c|c|c|c|c|c|c|c|}
\hline Year & Treatments & $\begin{array}{c}I \\
(\mathrm{~mm}) \\
\end{array}$ & $\begin{array}{c}E T \\
(\mathrm{~mm})\end{array}$ & $\begin{array}{l}\text { Yield } \\
\left(\mathrm{kg} \mathrm{ha}^{-1}\right)\end{array}$ & 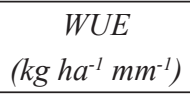 & 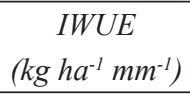 & $\begin{array}{l}I R c \\
(\%)\end{array}$ \\
\hline \multirow{10}{*}{2013} & $\mathrm{I}_{0}$ & - & 212.8 & $812.5 \mathrm{f}$ & 3.82 & - & - \\
\hline & $\mathrm{SA} 3-\mathrm{I}_{50}$ & 122.5 & 265.0 & $983.8 \mathrm{e}$ & 3.71 & 1.40 & 46.2 \\
\hline & SA3-I ${ }_{75}$ & 183.8 & 324.4 & $1137.0 \mathrm{~d}$ & 3.50 & 1.77 & 56.7 \\
\hline & SA3-I ${ }_{100}$ & 245.0 & 384.1 & $1222.2 \mathrm{c}$ & 3.18 & 1.67 & 63.8 \\
\hline & $\mathrm{SA}-\mathrm{I}_{50}$ & 127.8 & 278.9 & $1425.7 \mathrm{~b}$ & 5.11 & 4.80 & 45.8 \\
\hline & SA5-I ${ }_{75}$ & 191.7 & 334.8 & $1487.4 \mathrm{ab}$ & 4.44 & 3.52 & 57.3 \\
\hline & SA5- $I_{100}$ & 255.6 & 372.5 & $1562.6 \mathrm{a}$ & 4.19 & 2.93 & 68.6 \\
\hline & SA10-I ${ }_{50}$ & 127.8 & 242.7 & $1146.4 \mathrm{~d}$ & 4.72 & 2.61 & 52.6 \\
\hline & SA10-I ${ }_{75}$ & 191.7 & 275.8 & $1186.5 \mathrm{~d}$ & 4.30 & 1.95 & 69.5 \\
\hline & SA10-I ${ }_{100}$ & 255.6 & 323.1 & $1243.2 \mathrm{c}$ & 3.85 & 1.69 & 79.1 \\
\hline \multirow{10}{*}{2014} & $\mathrm{I}_{0}$ & - & 166.9 & $722.2 \mathrm{f}$ & 4.33 & - & - \\
\hline & SA3-I ${ }_{50}$ & 97.0 & 287.4 & $1073.2 \mathrm{e}$ & 3.73 & 3.62 & 33.8 \\
\hline & SA3-I ${ }_{75}$ & 145.5 & 352.8 & $1361.7 \mathrm{c}$ & 3.86 & 4.40 & 41.2 \\
\hline & SA3-I ${ }_{100}$ & 194.0 & 387.6 & $1461.0 \mathrm{bc}$ & 3.77 & 3.81 & 50.1 \\
\hline & SA5-I ${ }_{50}$ & 104.6 & 276.4 & $1183.2 \mathrm{de}$ & 4.28 & 4.41 & 37.8 \\
\hline & $\mathrm{SA} 5-\mathrm{I}_{75}$ & 166.9 & 322.8 & $1491.5 \mathrm{~b}$ & 4.62 & 4.61 & 51.7 \\
\hline & SA5-I ${ }_{100}$ & 209.2 & 359.7 & $1700.6 \mathrm{a}$ & 4.73 & 4.68 & 58.2 \\
\hline & SA $10-\mathrm{I}_{50}$ & 104.6 & 255.4 & $1085.4 \mathrm{e}$ & 4.25 & 3.47 & 41.0 \\
\hline & SA10-I ${ }_{75}$ & 166.9 & 290.3 & $1271.3 \mathrm{~d}$ & 4.38 & 3.29 & 57.5 \\
\hline & SA10-I ${ }_{100}$ & 209.2 & 350.5 & $1362.2 \mathrm{c}$ & 3.89 & 3.06 & 59.7 \\
\hline
\end{tabular}


increasing irrigation interval in all treatments. Average depletions of the available soil water holding capacity in $60 \mathrm{~cm}$ deep root zone during the vegetative season for full irrigation treatments were $29 \%$ (SA3), 40\% (SA5) and 60\% (SA10) in 2013 and 22\% (SA3), 29\% (SA5) and 50\% (SA10) in 2014.
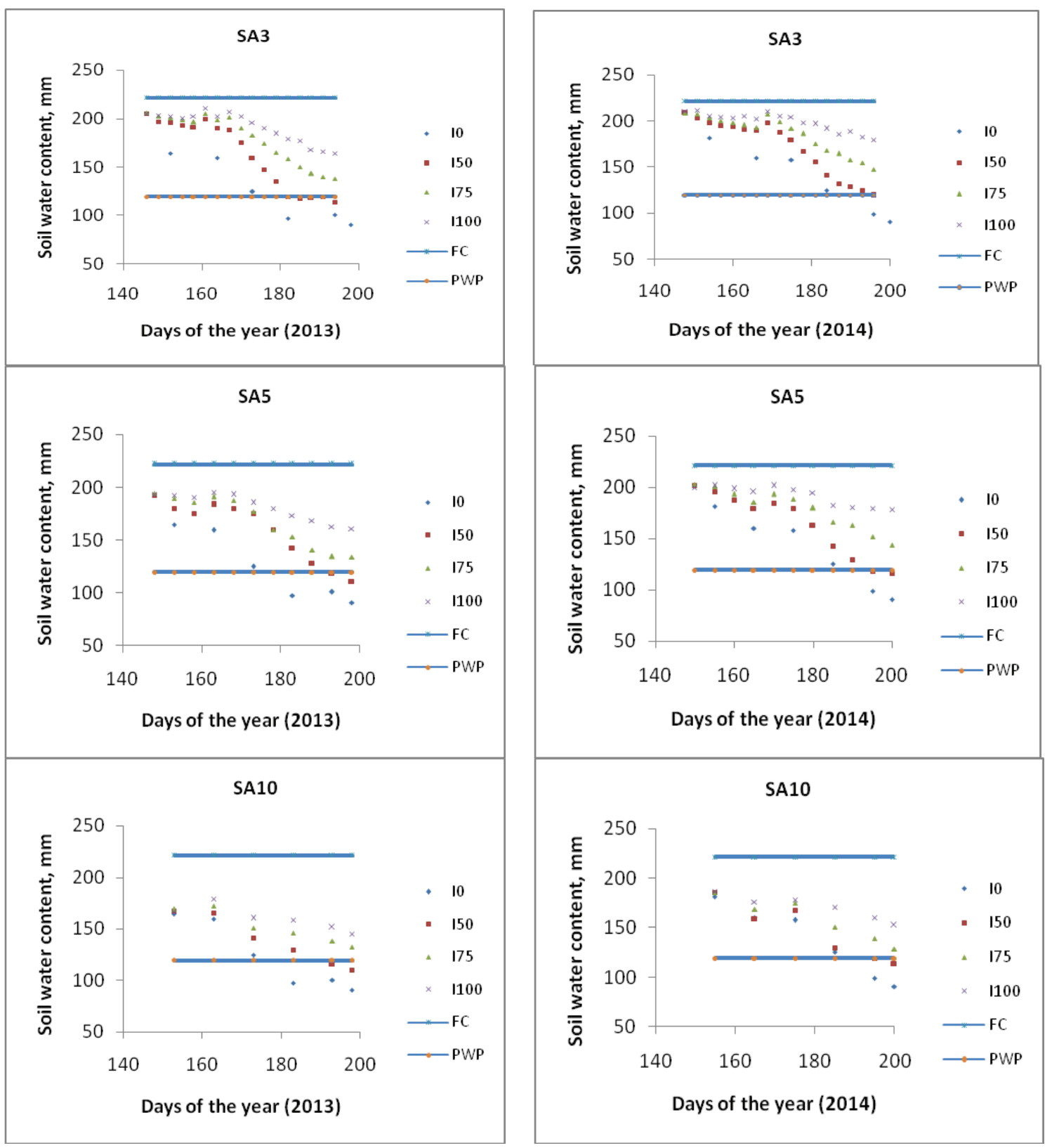

Figure 1- Soil water contents in $60 \mathrm{~cm}$ deep root zone before each irrigation 
Seed yield varied between $722.2\left(\mathrm{I}_{0}\right)$ and 1700.6 $\mathrm{kg} \mathrm{ha}^{-1}\left(\mathrm{SA} 5-\mathrm{I}_{100}\right)$ as seen in Table 3. The difference among the treatments was found to be statistically significant in each experimental year $(\mathrm{P}<0.05)$. While statistically the highest yield was obtained from SA5- $\mathrm{I}_{100}$ in both years, SA5- $\mathrm{I}_{75}$ was in the highest yield group with $1487.4 \mathrm{~kg} \mathrm{ha}^{-1}$ in the first year and followed SA5- $\mathrm{I}_{100}$ with $1491.5 \mathrm{~kg} \mathrm{ha}^{-1}$ in the second year. There was no significant difference between the yields obtained from same irrigation programs formed by different methods in both years. Black cumin seed yields reacted positively to an increase in the amount of irrigation water, and the effect of irrigation on the yield was observed to be highly significant compared to the conditions in which no irrigation was applied. While the results of this study were similar to those of Ahmed \& Haque (1986), Ozel et al (2009), Ghamarnia et al (2010), Al-Kayssi et al (2011) and Ghamarnia \& Jalili (2013) in terms of seed yield, the values obtained in this study were higher than those of Kalcin (2003) and Safaei et al (2014). Furthermore, the values obtained from the treatments with 5 days irrigation interval were generally found to be higher than others in which similar or equal amount of irrigation water was applied. The reason for this, it may be associated that the black cumin commonly cultivated in unirrigated conditions and resistant to drought could show negative response to more intensive and the frequency irrigation applied in SA3 compared to SA5. El-Mekawy (2012) found that the yield of black cumin in treatments that irrigation were applied 4 or 6 days intervals after flowering stage till harvesting time were higher than treatments with 2 days irrigation interval after flowering stage. In this study, irrigation covered generally the period after flowering time due to the realization of flowering on the $163^{\text {rd }}$ day of the year. Therefore, these results were in line with those of El-Mekawy (2012). Furthermore, the lower yield obtained in SA10 compared to SA5 could be due to water stress caused by low irrigation frequency which increased depletion of the available soil water holding capacity. The similar results were also reported by Al-Kayssi et al (2011).

\subsection{Water-yield functions}

\subsubsection{Water use efficiencies}

The highest and the lowest WUE values were calculated from SA5- $\mathrm{I}_{50}$ and $\mathrm{SA} 3-\mathrm{I}_{100}$ as 5.11 and 3.18 $\mathrm{kg} \mathrm{ha}^{-1} \mathrm{~mm}^{-1}$, respectively in the first year, and from SA5- $\mathrm{I}_{100}$ and $\mathrm{SA} 3-\mathrm{I}_{50}$ treatments as 4.73 and 3.73 $\mathrm{kg} \mathrm{ha}^{-1} \mathrm{~mm}^{-1}$, respectively in the second year (Table 3). In addition, the highest IWUE was calculated in SA5- $\mathrm{I}_{50}$, while the lowest was calculated in SA3- $\mathrm{I}_{50}$. In general, while WUE values were similar in both years, IWUE values in the first year were lower than those of the second year. The reasons of the differences can be explained with the higher total irrigation water amount applied in the first year because of pan evaporation methods used to form irrigation programs and less precipitation amount in the first year. The average WUE and IWUE values obtained in 5 days irrigation interval (4.56 and 3.85 $\mathrm{kg} \mathrm{ha}^{-1} \mathrm{~mm}^{-1}$ ) were higher than the other irrigation intervals. The WUE values calculated in the study were higher than WUE values found by Ghamarnia et al (2010) and Ghamarnia \& Jalili (2013). Although ET values were similar to those of the mentioned previous studies, this difference in WUE was may have been caused by the higher yields as a result of the variety of the seed, climatic differences and cultivation practices. While the coverage ratio of the applied irrigation water to the evapotranspiration (IRc) was determined between $79.1 \%\left(\mathrm{SA} 10-\mathrm{I}_{100}\right)$ and $33.8 \%\left(\mathrm{SA} 3-\mathrm{I}_{50}\right)$. The highest IRc values were obtained in the highest irrigation interval (SA10) and full irrigation treatments $\left(\mathrm{I}_{100}\right)$ according to both high irrigation frequency and deficit irrigation treatments. IRc values of the first year were higher than those of the second year was due to the plant water requirement was met more by precipitation in the second year because of higher precipitation.

\subsubsection{Graphical relationships}

In the experiment, linear relationships were obtained between the irrigation water amount and yield $\left(\mathrm{R}^{2}=0.520\right)$, and between the evapotranspiration and yield $\left(\mathrm{R}^{2}=0.660\right)$ at $0.1 \%$ significance level (Figure 2). Although the black cumin yield could be 
achieved even in the non-irrigated conditions, the relationships were observed that when irrigation water and ET increased, yield also increased.

\subsection{Yield response factor}

While SA5- $\mathrm{I}_{100}$ treatment was taken into consideration for ETm and Ym values in calculating mean yield response factor because of the highest yield obtained and no water stress observed, full irrigation $\left(\mathrm{I}_{100}\right)$ treatments were considered in calculating yield response factor for different irrigation intervals. The yield response factor (ky) values were calculated in SA3, SA5 and SA10 as $0.75,0.80$ and 0.50 , respectively and mean ky of all treatments was also calculated as 0.68 (Figure 3). Although the ky value obtained in the high irrigation interval (SA10) was lower than those obtained in the low irrigation interval (SA3, SA5), all ky values were lower than 1 . According to this result, the yield would decrease by only 0.68 units as a result of one unit deficit in the ET, it shows that black cumin plant is resistant to water deficit. It can be recommended that the deficit irrigation programs should be applied in the regions with limited water resources in order to increase the yield for black cumin plant which is widely cultivated under non-irrigated conditions especially.

\subsubsection{The effective root depth, yield and vegetative parameters}

The effective root depth of black cumin plant was determined as $27.25 \mathrm{~cm}$. The effective root depth determined in the study was consistent with the findings reported by Taqi (2013) that the total root length of black cumin varied between 52.87 and $60.80 \mathrm{~cm}$. For both years of the experiment, plant height, the number of branches, capsules, seeds in each capsule and a thousand seed weight values were obtained between 23.3 and $68.1 \mathrm{~cm}$, between 3.7 and 7.6 number plant ${ }^{-1}$, between 5.9 and 17.9 number plant ${ }^{-1}$, between 42.3 and 94.3 number capsules ${ }^{-1}$, and between 1.82 and $2.13 \mathrm{~g}$, respectively (Table 4). According to some yield and vegetative parameters, significant differences were found among the treatments, and the yield

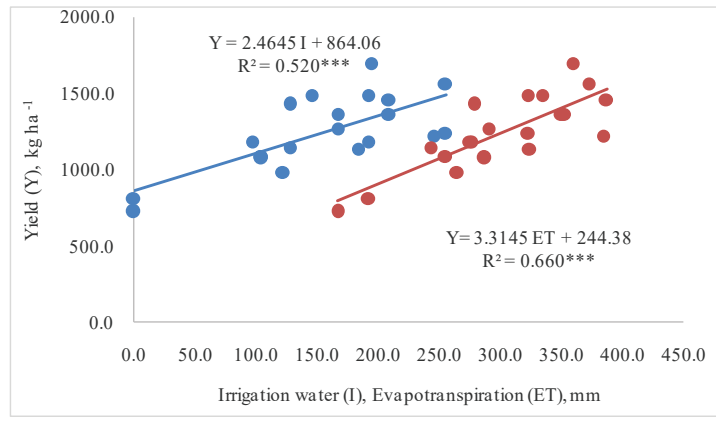

Figure 2- The relationships between irrigation water and yield, and evapotranspiration and yield

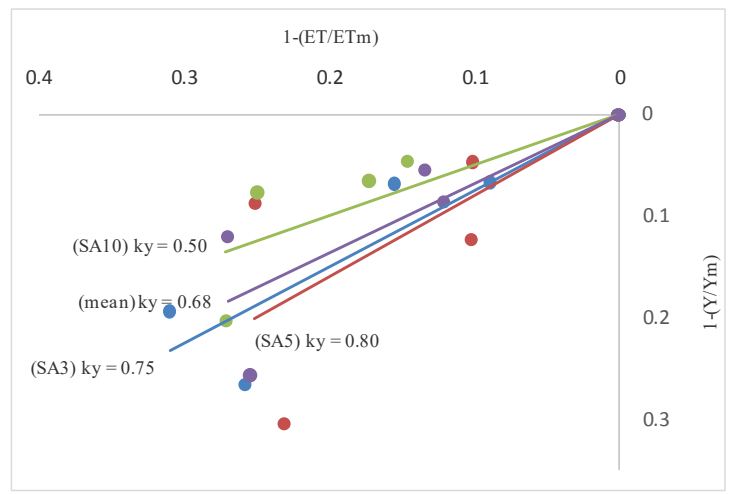

Figure 3- Yield response factor (ky) for all treatments and different irrigation intervals

and vegetative parameters of black cumin increased with the irrigation water amount $(\mathrm{P}<0.05)$. Except the harvest index value, while the values recorded in $\mathrm{I}_{0}$ (non-irrigated) were generally constituted the lowest group, the highest values were recorded in $\mathrm{I}_{100}$ and followed by $\mathrm{I}_{75}$. In addition, the values obtained from SA5 were generally higher than those obtained from SA3 and SA10. It was found out that the harvest index declined inversely to the increase in the irrigation water level due to the higher growth of the stem through irrigation, and it increased in the plots where less and no irrigation was applied due to the less growth of the stem. Although the findings obtained from the this study were generally higher than the findings of many researchers due to the controlled irrigation, it can be said that the 
Table 4- Some yield and vegetative parameters of black cumin

\begin{tabular}{|c|c|c|c|c|c|c|c|}
\hline Year & Treatments & $\begin{array}{l}\text { Plant } \\
\text { height } \\
(\mathrm{cm})\end{array}$ & $\begin{array}{c}\text { Number of } \\
\text { branches } \\
\text { (number plant }{ }^{-1} \text { ) }\end{array}$ & $\begin{array}{c}\text { Number of } \\
\text { capsules } \\
\text { (number plant }{ }^{-1} \text { ) }\end{array}$ & $\begin{array}{c}\text { Seed } \\
\text { number } \\
\left(\text { number capsule }^{-1}\right)\end{array}$ & $\begin{array}{c}\text { Thousand } \\
\text { seed weight } \\
\text { (g) }\end{array}$ & $\begin{array}{c}\text { Harvest } \\
\text { index } \\
(\%)\end{array}$ \\
\hline \multirow{10}{*}{2013} & $\mathrm{I}_{0}$ & $23.3 \mathrm{e}$ & $3.7 \mathrm{~g}$ & $5.9 \mathrm{~d}$ & $42.3 \mathrm{~h}$ & $1.82 \mathrm{f}$ & $23.0 \mathrm{a}$ \\
\hline & $\mathrm{SA} 3-\mathrm{I}_{50}$ & $41.0 \mathrm{~d}$ & $4.0 \mathrm{fg}$ & $7.7 \mathrm{~d}$ & $57.8 \mathrm{~g}$ & $1.93 \mathrm{e}$ & $18.0 \mathrm{e}$ \\
\hline & $\mathrm{SA} 3-\mathrm{I}_{75}$ & $48.9 \mathrm{c}$ & $4.4 \mathrm{ef}$ & $12.7 \mathrm{c}$ & $71.4 \mathrm{f}$ & $1.94 \mathrm{e}$ & $17.8 \mathrm{ef}$ \\
\hline & SA3-I ${ }_{100}$ & $51.6 \mathrm{~b}$ & $4.7 \mathrm{e}$ & $13.1 \mathrm{c}$ & $77.7 \mathrm{e}$ & $2.00 \mathrm{c}$ & $17.2 \mathrm{f}$ \\
\hline & $\mathrm{SA}-\mathrm{I}_{50}$ & $47.5 \mathrm{c}$ & $5.3 \mathrm{~cd}$ & $16.6 \mathrm{a}$ & $85.7 \mathrm{bc}$ & $1.82 \mathrm{f}$ & $16.9 \mathrm{~g}$ \\
\hline & SA5-I ${ }_{75}$ & $51.3 \mathrm{~b}$ & $5.6 \mathrm{c}$ & $15.6 \mathrm{~b}$ & $86.5 \mathrm{~b}$ & $2.03 \mathrm{bc}$ & $19.0 \mathrm{~d}$ \\
\hline & SA5-I ${ }_{100}$ & $53.5 \mathrm{a}$ & $7.6 \mathrm{a}$ & $17.9 \mathrm{a}$ & $94.3 \mathrm{a}$ & $2.12 \mathrm{a}$ & $18.0 \mathrm{e}$ \\
\hline & SA10-I & $48.0 \mathrm{c}$ & $4.8 \mathrm{de}$ & $11.2 \mathrm{c}$ & $80.5 \mathrm{~d}$ & $2.05 \mathrm{~b}$ & $17.0 \mathrm{fg}$ \\
\hline & SA $10-I_{75}$ & $50.2 \mathrm{bc}$ & $5.6 \mathrm{c}$ & $11.8 \mathrm{c}$ & $83.6 \mathrm{c}$ & $2.10 \mathrm{ab}$ & $21.4 \mathrm{~b}$ \\
\hline & SA10-I ${ }_{100}$ & $51.2 \mathrm{~b}$ & $6.6 \mathrm{~b}$ & $12.3 \mathrm{c}$ & $77.7 \mathrm{e}$ & $1.97 \mathrm{~d}$ & $20.7 \mathrm{c}$ \\
\hline \multirow{10}{*}{2014} & $\mathrm{I}_{0}$ & $49.1 \mathrm{~h}$ & $4.5 \mathrm{~d}$ & $7.5 \mathrm{f}$ & $74.1 \mathrm{e}$ & $1.95 \mathrm{de}$ & $28.0 \mathrm{a}$ \\
\hline & $\mathrm{SA} 3-\mathrm{I}_{50}$ & $55.4 \mathrm{~g}$ & $6.3 \mathrm{c}$ & $10.7 \mathrm{e}$ & $76.4 \mathrm{~d}$ & $1.97 \mathrm{~d}$ & $26.8 \mathrm{ab}$ \\
\hline & SA3-I ${ }_{75}$ & $57.1 \mathrm{f}$ & $7.3 \mathrm{ab}$ & $13.0 \mathrm{bc}$ & $78.2 \mathrm{c}$ & $2.01 \mathrm{c}$ & $20.3 \mathrm{f}$ \\
\hline & SA3- ${ }_{100}$ & $59.0 \mathrm{e}$ & $7.3 \mathrm{ab}$ & $13.7 \mathrm{ab}$ & $81.2 \mathrm{~b}$ & $2.03 \mathrm{bc}$ & $22.5 \mathrm{~d}$ \\
\hline & SA5-I ${ }_{50}$ & $64.9 \mathrm{~d}$ & $6.5 \mathrm{c}$ & $11.7 \mathrm{~cd}$ & $75.5 \mathrm{de}$ & $2.01 \mathrm{c}$ & $27.5 \mathrm{a}$ \\
\hline & $\mathrm{SA}-\mathrm{I}_{75}$ & $65.7 \mathrm{c}$ & $6.5 \mathrm{c}$ & $13.4 \mathrm{~b}$ & $80.3 \mathrm{~b}$ & $2.08 \mathrm{~b}$ & $20.9 \mathrm{e}$ \\
\hline & SA5-I ${ }_{100}$ & $65.9 \mathrm{c}$ & $7.0 \mathrm{~b}$ & $14.4 \mathrm{a}$ & $83.2 \mathrm{a}$ & $2.13 \mathrm{a}$ & $18.0 \mathrm{~g}$ \\
\hline & $\mathrm{SA} 10-\mathrm{I}_{50}$ & $58.6 \mathrm{e}$ & $7.0 \mathrm{~b}$ & $11.3 \mathrm{~d}$ & $74.3 \mathrm{e}$ & $1.94 \mathrm{e}$ & $25.6 \mathrm{bc}$ \\
\hline & $\mathrm{SA} 10-\mathrm{I}_{75}$ & $67.2 \mathrm{~b}$ & $7.2 \mathrm{ab}$ & $12.4 \mathrm{c}$ & $77.7 \mathrm{c}$ & $1.98 \mathrm{~d}$ & $24.0 \mathrm{~cd}$ \\
\hline & $\mathrm{SA}^{10-\mathrm{I}_{100}}$ & $68.1 \mathrm{a}$ & $7.5 \mathrm{a}$ & $12.8 \mathrm{bc}$ & $77.9 \mathrm{c}$ & $2.05 \mathrm{~b}$ & $22.3 \mathrm{~d}$ \\
\hline
\end{tabular}

difference with the findings of other researchers was based on the irrigation, soil and climatic features (Ghamarnia et al 2010; Akgoren 2011; Taqi 2013; Ghamarnia \& Jalili 2013; Safaei et al 2014).

\section{Conclusions}

Consequently, it was revealed that irrigation was inevitable to obtain higher yield in black cumin plant which generally grows under non-irrigated conditions. Considering the water-yield functions, it can be recommended that the irrigation interval should be 5 days, irrigation water amount should be applied to meet full evapotranspiration requirement under conditions where the water is sufficient, or the maximum deficit should not exceed $25 \%$ of full irrigation under limited water conditions in the irrigation schedules for black cumin. In addition, both of the pan evaporation and water balance methods can be used for irrigation of black cumin, since the values of the yield and vegetative parameters and ET in the same irrigation programs formed by two different methods were close to each other. Especially, pan evaporation which is simple method to obtain irrigation programs, can be preferred because of low cost, labor and easy operation.

\section{Acknowledgements}

The authors would like to thank Suleyman Demirel University [Project Number $=$ SDU-BAP: 3727-YL213] for supporting of the project. Some of the data used in this manuscript was taken from Master Thesis.

\section{References}

Ahmed N U \& Haque K R (1986). Effect of row spacing and time of showing on the yield of black cumin (Nigella sativa L.). Bangladesh Journal of Agricural Research 11(1): 21-24 
Akgoren G (2011). Agricultural features of some black cumin (Nigella sativa L.) populations. MSc Thesis, Osman Gazi University (Unpublished), Eskisehir

Al-Kayssi A, Shibab R M \& Mustafa S H (2011). Impact of soil water stress on Nigellone oil content of black cumin seeds grown in calcareous-gypsifereous soils. Agricultural Water Management 100: 46-57

Baydar H (2013). The Science and Technology of Medicinal and Aromatic Plants. $1^{\text {st }}$ Ed. Süleyman Demirel University, Isparta

Doorenbos J \& Pruitt W O (1977). Crop water requirements. Irrigation and Drainage Paper, No. 24 FAO, Rome, pp. 179

Doorenbos J \& Kassam A H (1986). Yield response to water. Irrigation and Drainage Paper, No. 33. FAO, Rome, pp. 193

El-Mekawy M A M (2012). Growth and yield of Nigella sativa L. plant influenced by sowing date and irrigation treatments. American-Eurasian Journal of Agriculture \& Environmental Science 12(4): 499-505

English M \& Raja S N (1996). Perspectives on deficit irrigation. Agricultural Water Management 32: 1-14

Ghamarnia H \& Jalili Z (2013). Water stress effects on different Black cumin (Nigella sativa L.) components in a semi-arid region. International Journal of Agronomy and Plant Production 4(4): 753-762

Ghamarnia H, Khosravy H \& Sepehri S (2010). Yield and water use efficiency of (Nigella sativa L.) under different irrigation treatments in a semi arid region in the West of Iran. Journal of Medicinal Plants Research 4(16): 1612-1616

Howell T A, Cuenca R H \& Solomon K H (1990). Crop yield response. In: Management of Farm Irrigation Systems. ASAE, Madison, Wisconsin, pp. 312

James L G (1988). Principles of farm irrigation system design. John Wiley and Sons. Inc., New York, pp. 543

Kalcin F T (2003). Effect of plant density on yield and yield components on two black cumin species (Nigella sativa L. Nigella damascena L.). MSc Thesis, Ankara University (Unpublished), Ankara

Kanber R (1984). Çukurova koşullarında açık su yüzeyi buharlaşmasından yararlanarak birinci ve ikinci ürün yerfıstığının sulanması [in Turkish]. Bölge Topraksu Araştırma Enstitüsü Yayınları 114(64), Tarsus, Türkiye

Kanber R (1997). Irrigation. $1^{\text {st }}$ Ed. Cukurova University, Academic Press, Adana, pp. 140-142

Kanber R (2010). Field Irrigation Systems. $1^{\text {st }}$ Ed. Cukurova University, Academic Press, Adana, pp. 402-490

Kumar S A (2009). Plants-based Medicines in India. Retrieved in February, 15, 2013 from http://pib.nic.in/ feature/feyr2000/fmay2000/f240520006.html

Ozel A, Demirel U, Guler I \& Erden K (2009). Effect of different row spacing and seeding rates on black cumin (Nigella sativa L.) yields and some agricultural characters. University of Harran Journal of the Faculty of Agriculture 13(1): 17-25

Panda R K, Behera S K \& Kashyap P S (2004). Effective management of irrigation water for maize under stressed conditions. Agricultral Water Management 66: $181-203$

Safaei Z, Azizi M, Maryam Y, Aroiee H \& Davarynejad $\mathrm{G}$ (2014). The effect of different irrigation intervals and anti-transpiration compounds on yield and yield components of black cumin (Nigella sativa L.). International Journal of Advanced Biological and Biomedical Research 4(2): 326-335

Taqi H (2013). Determination of important agricultural and quality characters of some black cumin (Nigella sativa L.) populations under Samsun ecological conditions. MSc Thesis, Ondokuz Mayıs University (Unpublished), Samsun

TUIK (2015). Turkish Statistical Institute, Retrieved in February, 20, 2015 from http://www.tuik.gov.tr/

Wang Z, Liu Z, Zhang Z \& Liu X (2009). Subsurface drip irrigation scheduling for cucumber (Cucumis sativus L.) grown in solar greenhouse based on $20 \mathrm{~cm}$ standard pan evaporation in Northeast China. Scientia Horticulturae 123: 51-57

Yazar A, Sezen S M \& Gencel B (2002). Drip irrigation of corn in the Southeast Anatolia project (GAP) area in Turkey. Irrigation and Drainage 51: 293-300 